\title{
Green Synthesis of Nickel Nanoparticles using Fruit Peels of Citrus Paradise for Remediation of Congo Red Dye
}

\author{
Shumaila Kiran ${ }^{1 *}$, Muhammad Asim Rafique ${ }^{2}$, Asma Ashraf ${ }^{3}$, Tahir Farooq ${ }^{1}$, Sarosh Iqbal ${ }^{1}$, Gulnaz \\ $\mathrm{Afzal}^{4}$, Saba Ajmal ${ }^{1}$, Saba Naz \\ ${ }^{1}$ Department of Applied Chemistry, Government College University, Faisalabad-38000, Pakistan. \\ ${ }^{2}$ School of Economics and Management, Yanshan University, Qinhuangdao Shi, Hebei Sheng, China. \\ ${ }^{3}$ Department of Zoology, Government College University, Faisalabad-38000, Pakistan. \\ ${ }^{4}$ Department of Zoology, Islamia University, Bahawalpur, Pakistan.
}

*Corresponding author: Shumaila Kiran, email: shumaila.asimch@,gmail.com

Received January $1^{\text {st }}, 2021 ;$ Accepted June $8^{\text {th }}, 2021$.

DOI: http://dx.doi.org/10.29356/jmcs.v65i4.1572

\begin{abstract}
Biosorption is a cost-effective excellent tool for removing problematic dyes. The present work was focused on the utilization of Citrus paradise (grapefruit) peels aqueous extract for synthesis of nickel nanoparticles. The prepared nanoparticles were characterized by SEM and were used for the remediation of congo red direct dye. The decolorization of Congo Red direct dye was measured using UV/Visible spectrophotometer following the optimization of experimental factors. Maximum decolorization was observed at a dye concentration of $0.02 \%, \mathrm{pH} 6$, at $50{ }^{\circ} \mathrm{C}$ temperature, and catalyst dose was $0.01 \mathrm{~g} / \mathrm{L}$. TOC and COD values were found to be $79.89 \%$ and $78.23 \%$. Agriculrural waste could be used for the remediation of other synthetic dyes as well; hence helps in cleaning our natural environment.
\end{abstract}

Keywords: Congo red direct dye; grapefruit peel; Ni nanoparticles; remediation.

Resumen. La biosorción es una excelente herramienta rentable para eliminar colorantes problemáticos. El presente trabajo se centró en la utilización del extracto de cáscaras de Citrus paradise (pomelo) para la síntesis de nanopartículas de níquel. Las nanopartículas preparadas se caracterizaron por microscopía electrónica de barrido (MEB) y se utilizaron para la remediación del colorante directo rojo de Congo. La decoloración del colorante directo Rojo Congo se midió mediante espectrometría siguiendo la optimización de factores experimentales. Se observó una decoloración máxima a una concentración de colorante de $0.02 \%$, pH 6 , y una temperatura de $50{ }^{\circ} \mathrm{C}$; la dosis del catalizador fue de $0.01 \mathrm{~g} / \mathrm{L}$. Se determinó que los valores de TOC y DQO eran $79.89 \%$ y $78.23 \%$, respectivamente. Los residuos agrícolas también podrían utilizarse para la remediación de otros tintes sintéticos y con ello ayudar a limpiar nuestro entorno natural.

Palabras clave: Colorante directo rojo congo; cáscara de pomelo; nanopartículas de Ni; remediación.

\section{Introduction}

Textile manufacturing units are found in many countries and use large number of synthetic dyes as the coloring agents. Dyes contain different organic compounds, mainly founded on the heterocyclic and aromatic species such as aromatic amines that are carcinogenic in nature [1]. Most of synthetic dyes contain azo group. 
These dyes cause environmental pollution so there is necessity for dyes decontamination via a proper ttreatment syntsm before their final disposal into water systems [2]. Many physical, chemical, and biological methods are in use for elimination of dyes [3-9]. These methods have one or other limitations, and none of them is successful in the complete removal of dyes [10-12]. A comprehensive overview of previous studies done on congo red direct dye is given in following table 1 .

Table 1. Comparison of previous studies on decolorization/degradation of congo red dye.

\begin{tabular}{|c|c|c|l|}
\hline Sr.\# & $\begin{array}{c}\text { Mean of study of } \\
\text { decolorization of Congo } \\
\text { red dye }\end{array}$ & Year & \multicolumn{1}{|c|}{ Weak Points } \\
\hline 1 & Ozonation & 2014 & $\begin{array}{l}\text { The lifetime of ozone is quite low almost } 20 \\
\text { minutes. The unceasing supply of ozone is } \\
\text { essential during the whole experimentation via a } \\
\text { controlled way. It is being a chemical method non } \\
\text { eco-friendly in nature. }\end{array}$ \\
\hline 2 & Using bacterial isolates & 2017 & $\begin{array}{l}\text { Biological methods are eco-friendly in nature, but } \\
\text { not low-cost one as many compounds are vital for } \\
\text { bacterial strains as their growth media. }\end{array}$ \\
\hline 3 & Using fungi & 2018 & $\begin{array}{l}\text { Biological means are eco-friendly, but not } \\
\text { cheaper one as various chemicals are required for } \\
\text { fungal strains as their growth media. }\end{array}$ \\
\hline 4 & $\begin{array}{c}\text { Nickel oxide nanoparticles } \\
\text { prepared using chemical } \\
\text { method }\end{array}$ & 2020 & $\begin{array}{l}\text { The chemical approach is costly and not eco- } \\
\text { friendly }\end{array}$ \\
\hline
\end{tabular}

The removal of dyes from wastewater is completely done by nanoparticles which are synthesized by greenway using the agricultural waste materials. This green process is eco-friendly and inexpensive [13-14]. Several kinds of metal nanoparticles are fruitfully made from agrowaste materials. Extracts of agrowaste materials are used as stabilizing and reducing agents for the synthesis of metal nanoparticles. These nanopartilces are exhibited various capabilities like antimicrobial, antioxidant, catalytic to cytotoxicity against cancer cells [15]. Several biotechnological processes have been developed towards the utilization of agrowastes to improve the nutritional qualities by solid-state fermentation, production of enzymes, organic acids, and as renewable materials to produce biogas [16].

Grapefruit (Citrus paradisi) is an evergreen tree belonging to the Rutaceae family. Originally grapefruit appeared on Barbados Island, but in the $19^{\text {th }}$ century first, trees were planted in Florida, where its cultivation continues up to this day. In Pakistan, grapefruit is a significant fruit owing to its significant remedial benefits [17]. Nickel can exist in the form of nickel metal and nickel oxide nanoparticles. These two classes of nanoparticles possess magnetic properties, biocompatibility, catalytic activity, antimicrobial activity, and sorption nature. The synthesis of nickel-based nanoparticles produced by chemical and physical methods is costly, involve complicated procedures, and cause environmental pollution besides low productivity [18]. So, researchers are trying to develop green methods-based biomaterials especially with the plant extracts [19]. Present study was intended to make nickel nanoparticles using grapefruit peels and the synthesized nickel nanoparticles were applied in the deletion of notorious congo red direct dye. 


\section{Experimental}

This task was intended to build up an ecofriendly process for the synthesis of nickel nanoparticles and decolorization of congo red direct dye. In the first part, nickel nanoparticles (Ni-NPs) were synthesized by greenway and in the $2^{\text {nd }}$ part, optimized parameters were used for the decolorization of congo red direct dye (Fig. 1) using synthesized nickel nanoparticles (Ni-NPs).<smiles>Nc1c(N=Nc2ccc(-c3ccc(N=Nc4cc(S(=O)(=O)[O-])c5ccccc5c4N)cc3)cc2)cc([N+](=O)[O-])c2ccccc12</smiles>

Fig. 1. Structure of Congo Red Direct dye.

\section{Sample collection}

Citrus paradisi peels were taken from the native market of city Faisalabad, Punjab, Pakistan. Then these freshly collected grapefruit peels were washed with tap water to make it dust free, dried and re-washed with distilled water for complete cleaniness and then air dried in shade. Then the dried biomass was ground, strained and saved in an airtight container.

\section{Preparation of Citrus paradisi (grapefruit) peel extract}

Fine powder of grapefruit peel $(5 \mathrm{~g})$ was taken into the $500 \mathrm{~mL}$ flask comprising $225 \mathrm{~mL}$ distilled water then put in a water bath at $90^{\circ} \mathrm{C}$ for 15 minutes. After heating, the extract was air-cooled and got filtered. This extract was centrifuged for $15 \mathrm{~min}$. at $5000 \mathrm{rpm}$ and the solution was filtered [20].

\section{Nickel nanoparticles synthesis (Ni-NPs)}

$0.3 \mathrm{M}$ solution of nickel nitrate was prepared by dissolving $18.2 \mathrm{~g}$ of nickel nitrate in $333 \mathrm{~mL}$ distilled water. The color of the nickel nitrate solution was green. Then $300 \mathrm{~mL}$ of $0.3 \mathrm{M}$ aqueous solution of nickel nitrate and $30 \mathrm{~mL}$ of grapefruit extract was taken in a beaker and mixed well. The solution was changed into bluish-green precipitates. After 1 day, the bluish-colored precipitates were made at the end of the vessel. These precipitates were then centrifuged, filtered and the residue remained to wash away numerous times with distilled water to eliminate unwanted materials to yield the nickel nanoparticles (Ni-NPs) [20].

\section{Characterization of nanoparticles}

The Ni-NPs were characterized by scanning electron microscope (SEM). SEM offers thorough great resolved pictures of the speciman by fostering a intensive electron ray through the surface of specimen and noticing the recieved electron signals. SEM images of synthesized nickel nanoparticles were recorded using Hitachi S-4500 instrument (made in America) using a carbon-coated copper film for loading the powdered nanoparticles on it.

\section{Experimental Procedure}

The direct red dye solution was taken in a reaction vessel and Ni-NPs were added. $\mathrm{pH}$ was maintained up to 5. The reaction vessel was kept on a magnetic stirrer for 90 minutes and a small aliquot from reaction mixture was taken out after every 15 minute to check its absorbance using a UV-Visible double beam spectrophotometer. For the decolorization of congo red direct dye, dye concentration (0.01-0.1\%), pH (4-8), Ni-NPs concentration $(1-5 \mathrm{mg} / 50 \mathrm{~mL})$ and temperature $\left(40-70{ }^{\circ} \mathrm{C}\right)$ were optimized. One parameter was changed at a time keeping the other parameters intact. 


\section{Chemical analysis}

All decolorization experiments were run thrice. The absorbance of all untreated and treated dye solutions was checked by measuring the absorbance at $\lambda_{\max }$ value using a UV-Visible double beam spectrophotometer (Model UV-1800, Himadzu Corporation Japan). The spectrophotometer was calibrated first with blank (water) and then was used for analysis of research samples. Quartz cuvets were used to hold the blank and sample. The decolorization (\%) was calculated using the formula given below:

$$
\text { Decolorization }(\%)=(\mathrm{I}-\mathrm{F}) / \mathrm{I} \times 100
$$

where, $\mathrm{I}$ is the primary absorbance and $\mathrm{F}$ shows the absorbance of treated dye solution.

\section{Mineralization study}

Both treated \& untreated dye solutions were evaluated by TOC and COD measurements.

\section{Total organic carbons (TOC)}

The total organic carbon (TOC) was estimated to check the quantity of organic materials present in treated dye samples. Then a comparision was made between treated sample TOC value and untreated sample TOC value. For it, digestion vials were taken having $1 \mathrm{~mL}$ of $\mathrm{K}_{2} \mathrm{Cr}_{2} \mathrm{O}_{7}(2 \mathrm{~N})$ and $1.5 \mathrm{~mL} \mathrm{H}_{2} \mathrm{SO}_{4}(98 \%)$. Test sample $(4 \mathrm{~mL})$ was added in the vials. The vial having all materials except test sample named as blank. Digetsion vials wre kept in an oven at $110-115^{\circ} \mathrm{C}$ for 90 minutes. Aftre that, vials wer cooled and the absorbance was recorded at $\lambda_{\max } 590 \mathrm{~nm}$ using double beam spectrophotometer. The blank absorbance was deducted from test specimen absorbance [21]. Results were calculated in terms of percent reduction in TOC.

\section{Chemical Oxygen Demand (COD)}

For COD measurements, $3.5 \mathrm{~mL}$ of catalyst solution (which was prepared by taking $5 \mathrm{~g}^{\text {of }} \mathrm{Ag}_{2} \mathrm{SO}_{4}$ in $500 \mathrm{~mL}$ conc. $\mathrm{H}_{2} \mathrm{SO}_{4}$ by placing for $48 \mathrm{~h}$ ) and $1.5 \mathrm{~mL}$ of digestion solution (which was prepared by taking $\mathrm{K}_{2} \mathrm{Cr}_{2} \mathrm{O}_{7}(2.58 \mathrm{~g})$ and $\mathrm{HgSO}_{4}(8.3 \mathrm{~g})$ in $\mathrm{H}_{2} \mathrm{SO}_{4}(40 \mathrm{~mL})$ and diluted it to $250 \mathrm{~mL}$ using deionized water) were taken in vials. Treated dye solution $(2.5 \mathrm{~mL})$ was put in the digestion vial. Blank contained all the chemicals except dye treated. The vials were kept in an oven for 120 minutes at $150{ }^{\circ} \mathrm{C}$, cooled and absorbance was recorded at $600 \mathrm{~nm}$. Blank absorbance was deducted from the treated sample absorbance [21]. Results were calculated in terms of percent reduction in COD.

\section{Degradation study}

The degradation products of congo red direct dye were judged by studying a detailed mechanistic study which showed the rupturing of old bonds and formation of new ones.

\section{Statistical analysis}

All experiments were carried out in thrice and data was computed using standard error of means [22].

\section{Results and discussion}

\section{Scanning of $\lambda_{\max }$}

To find the wavelength of maximum absorbance $\left(\lambda_{\max }\right)$, the absorbance was varied from 400 to 700 $\mathrm{nm}$ in intervals of $20 \mathrm{~nm}$. $\lambda_{\max }$ was found to be $500 \mathrm{~nm}$ (Fig. 2). 


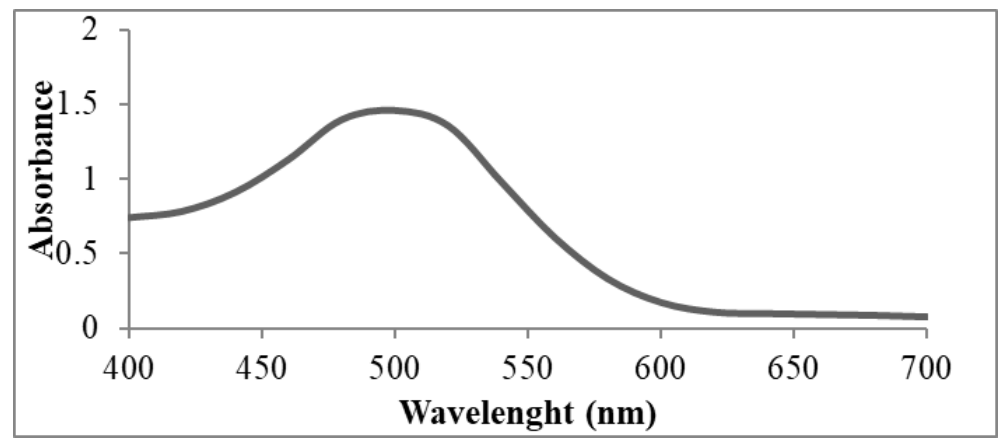

Fig. 2. Determination of $\lambda_{\max }$ for Congo Direct Red Dye under study.

\section{SEM analysis}

SEM study was using to show the magnitude and form of nanoparticles of nickel. SEM picture of nickel nanoparticles formed by the green synthesis method is shown in Fig. 3. The prepared nanoparticles were found to be sphere-shaped and poly-dispersed with diameters having a range of 50-70 nm.

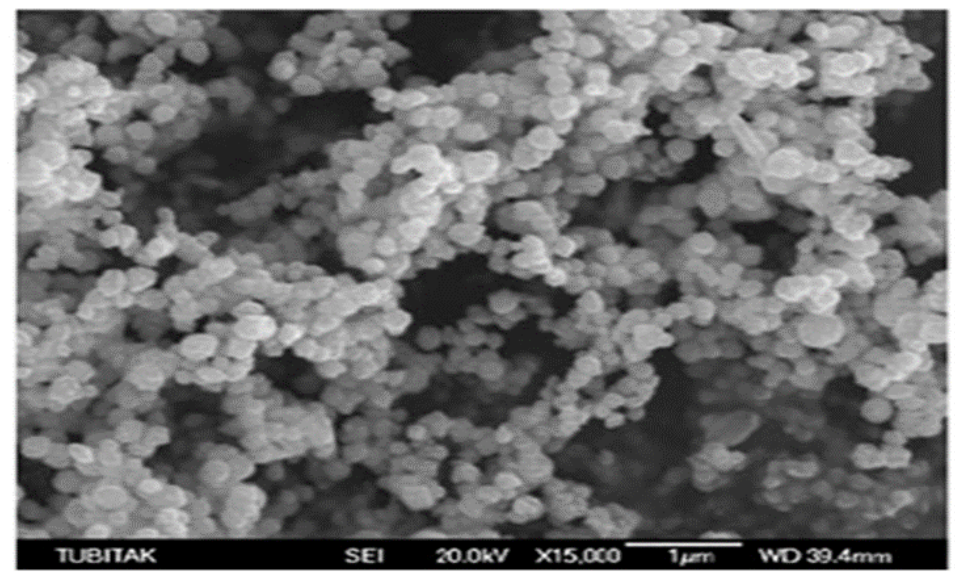

Fig. 3. SEM image of Ni nanoparticles synthesized using Citrus paradise peel extract.

\section{Optimization of experimental conditions to decolorize congo red direct dye}

The amount of a synthetic dye is a very important parameter which is important to be optimized. Here in current study, the concentration of congo red direct dye was optimized by varying its concentration from $0.01 \%$ to $0.05 \%$. As the concentration of congo red direct dye was varied from $0.01 \%$ to $0.02 \%$ with various time intervals (15-90 minutes), it enhanced the decolorization of congo red direct dye from $32.70 \%$ to $70.17 \%$ in $60 \mathrm{~min}$. The target dye decolorization (\%) was decreased with the further increase in its concentration i.e. from 0.03 to $0.05 \%$ (Fig. 4(a)). The adsorption ability and decolorization efficacy by adsorbent (nickel nanoparticles) are in direct link with the contact time. As the contact time increases, the dye molecules get sufficient time for maximum adsorption on the catalyst surface up to a fixed limit. An equilibrium is established between the dye molecules adsorbed and those of unadsorbed ones. High concentration of dye may cause aggregation of dye particles due to self-association which may decrease dye affinity towards the catalyst $[23,24]$.

The catalyst dose is an essential parameter as it is directly linked to the number of active sites responsible for catalytic activity. To optimize the catalyst dose, experiments were run using varying 
concentrations $(0.001-0.009 \mathrm{~g} / \mathrm{L})$ of nickel nanoparticles keeping the previously optimized dye concentration constant. As the concentratiuon of nickel nanoparticles was increased from 0.001 to $0.007 \mathrm{~g} / \mathrm{L}$, the decolorization (\%) was found to be raised from $50.8 \%$ to $72 \%$ in 60 minutes of contact time (Fig. 4(b)). The increase in catalyst dose results in the greater number of active sites to adsorb more number of dye molecules, which in turn increase the dye decolorization. However, it has been pointed out in previous studies that a catalyst is efficient at a particular dose only. After that level, the reaction rate may be decreased [24]. The possible reason for decreasing the decolorization of direct dye at a higher concentration of nickel nanoparticles is that the destruction/change in the surface of catalyst by the products of the reaction; hence declining the catalytic efficiency of nanoparticles [25].

The effect of $\mathrm{pH}$ on decolorization of congo red direct dye was studied using dye concentration $0.02 \%$ and $0.007 \%$ nickel nanoparticles dose. $\mathrm{pH}$ range was varied from $4-8$. The decolorization (\%) increased as $\mathrm{pH}$ was increased from 4 to 6 . The maximum decolorization (75.5\%) was obtained at pH 6 (Fig. 4 (c)). Further increase in $\mathrm{pH}$ resulted in decline in decolorization. $\mathrm{pH}$ plays a significant role in the catalytic action of a catalyst. A minor change in $\mathrm{pH}$ may cause a great alteration in reaction efficacy [26]. Nickel nanoparticles showed their maximum adsorption capacity at $\mathrm{pH} 6$ hence causing maximum decolorization of congo red direct dye at this $\mathrm{pH}$. Further increase in $\mathrm{pH}$ may cause a temporary or permanent change in the catalyst surface, hence effecting its catalytic action badly [27]. Catalyst works better at optimum $\mathrm{pH}$ merely owe to participation of a maximum figure of active places at optimum $\mathrm{pH}$ [28]. Higher $\mathrm{pH}$ may cause an alteration in specific structural geometry of catalyst, henceforth is a basis of deterioration in catalytic effectiveness of catalytic agent [29].

Similarly, influence of temperature $\left(40-70^{\circ} \mathrm{C}\right)$ on congo red dye decolorization $(\%)$ in the presence of nickel nanoparticles was also investigated. With a rise in temperature from 40 to $50^{\circ} \mathrm{C}$, the percentage of dye decolorization was raised from $68.5 \%$ to $87.5 \%$, as it is evident from Fig. 4(d). Catalysts are capable to adsorb direct dyes on their surface at a particular temperature only. This temperature is the optimum temperature. The catalyst efficiency may get decreased if it is exposed to temperature higher than its optimum level. It might be due to the change in three-dimensional configuration of the catalyst surface, hence effecting the catalytic proficiency of nickel nanoparticles [30].
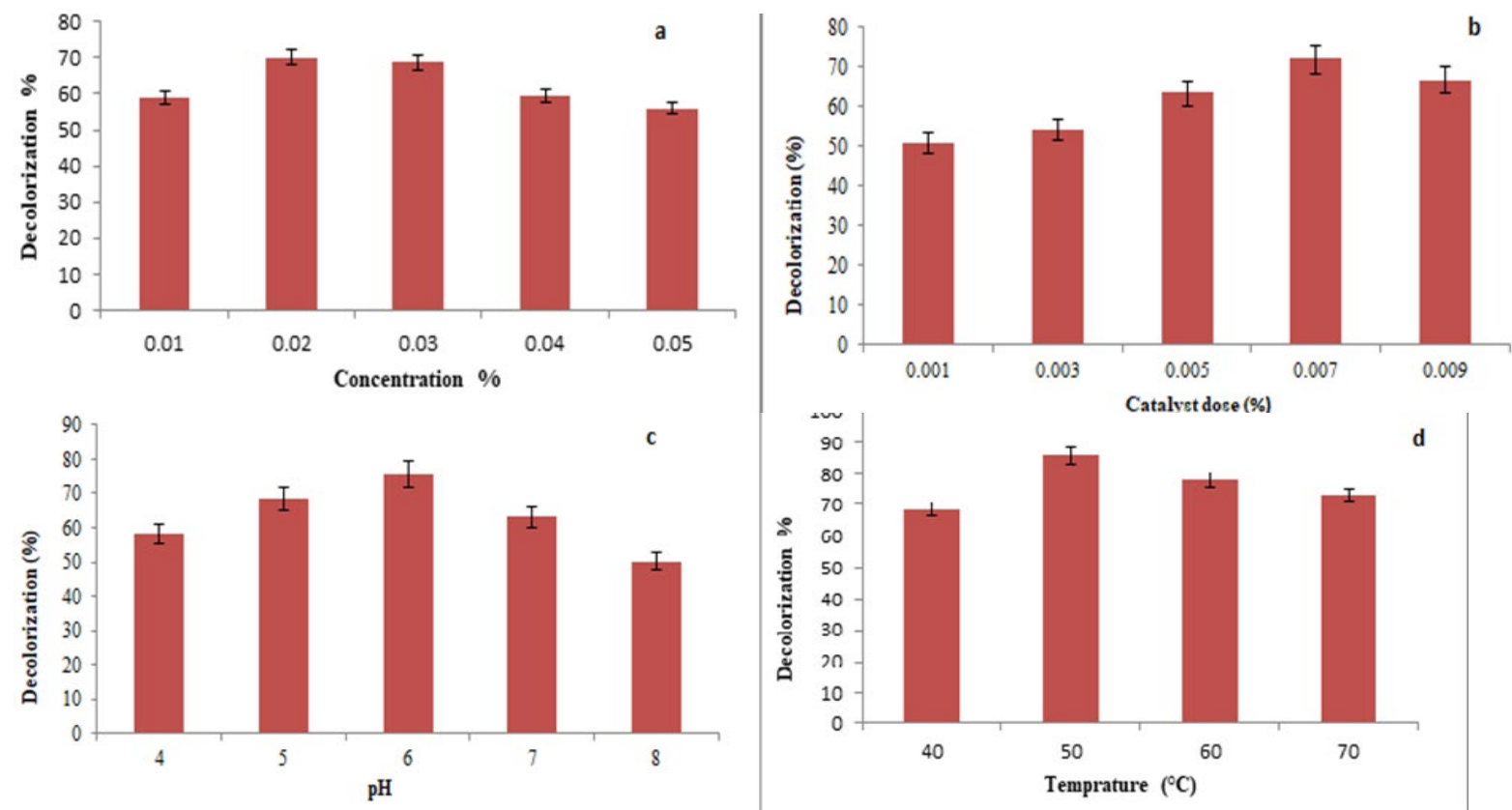

Fig. 4. Effect of concentration of dye, (a) Effect of concentration of nanoparticles, (b) Effect of pH, (c) Effect of temperature (d) on decolorization (\%) of Congo Red direct dye. 


\section{Mineralization study}

Investigation of water quality parameters like total organic carbon (TOC) and chemical oxygen demand (COD) of treated samples of congo red direct dye using nickel nanoparticles was carried out to assess the mineralization efficacy. In catalytic treatment, decrease (\%) in COD and TOC were found to be $78.23 \%$ and $79.89 \%$, as shown in Fig. 5. It ran to a steady rise in decrease (\%) in both TOC and COD values with the increase in contact time which has shown the mineralization efficiency of degradation of congo red direct dye using bio-synthesized nickel nanoparticles acting as a catalyst $[31,32]$.

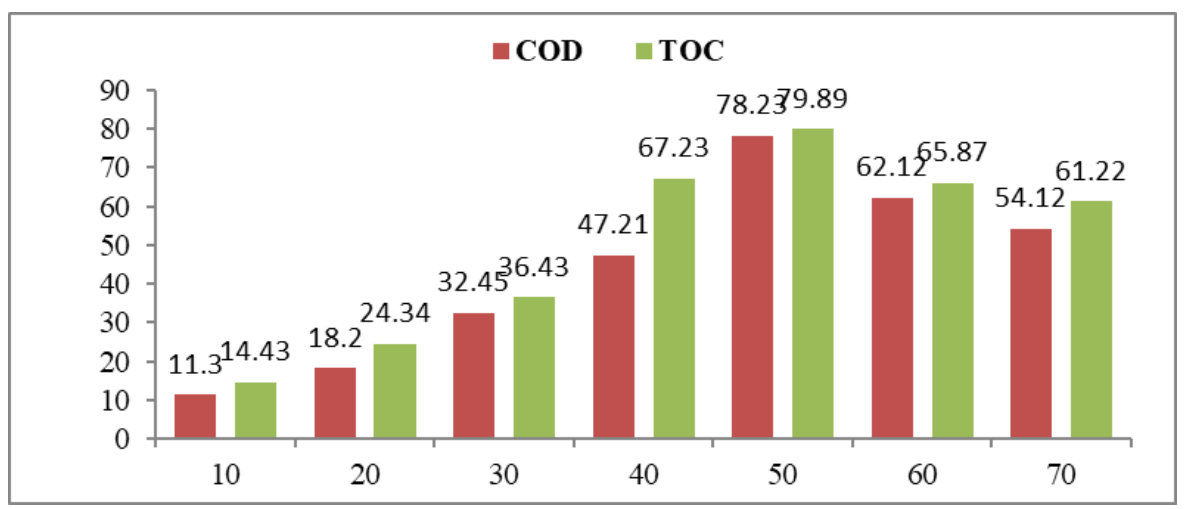

Fig. 5. Effect of catalytic Treatment contact time (min.) on water quality parameters.

\section{Degradation pathway of Congo red Direct dye}

Congo red dye belongs to azo dyes. The dye underwent degradation via different steps. First of all, azo bond was broken as it is evident in Fig. 6. The dye molecule is degraded via breaking of the chromophore group. After that, the intermediates are converted into low molecular weight compounds like aldehyde and ketone that are further breakdown into carbon dioxide and water $[33,34]$.

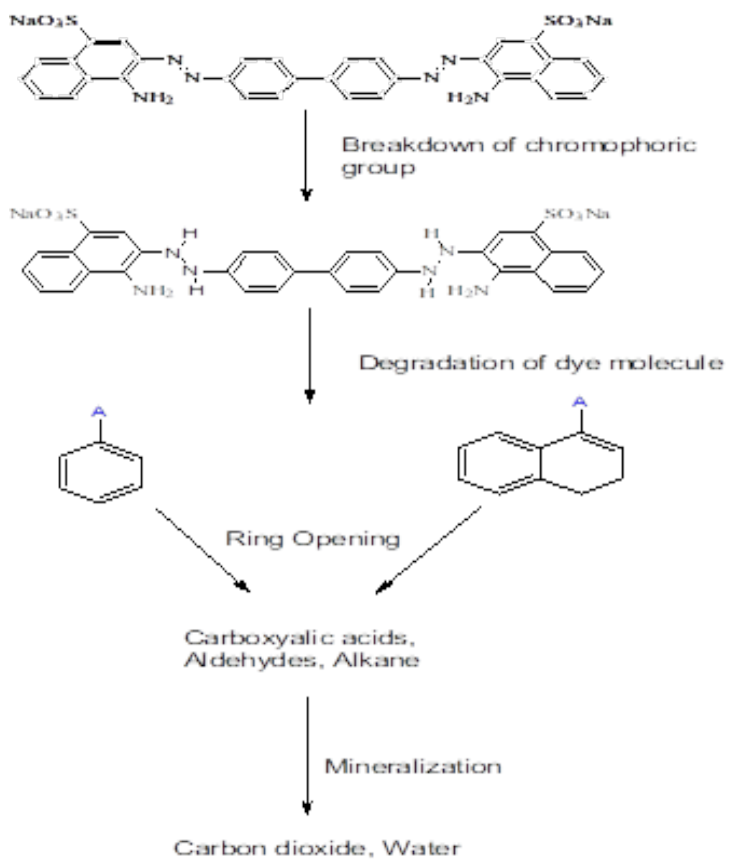

Fig. 6. Degradation pathway of Congo Red direct dye. 


\section{Conclusion}

Agricultural wastes being cheaper and easily available sources could be successively used for the synthesis of metal nanoparticles for their environmnetal applications. Grapefruit peel which is low cost and ecofriendly sorbent was used for the green synthesis of nickel nanoparticles. In the current study, nickel nanoparticles were successively sunthesized using aqueous extract of grapefruit peels, which were then applied for the decolorization of congo red direct dye. Almost $88 \%$ of the target dye was decolorized at optimum experimental conditions. Percent reduction in COD and TOC has shown the great effectiveness of current studied method. It can be inferred from the current study that grapefruit peel could be the best candidate for the mineralization of other toxic dyes as well. Hence, it can be concluded that the current study is basically is the valorization of waste where an agriclurural waste was successively applied for the removal of a toxic dye via synthesis of nickel nanoparticles.

\section{Acknowledgements}

The authors are highly thankful to the department of applied chemistry for providing chemicals to carry out the current study.

\section{References}

1. Edison, T.; Atchudan, R.; Sethuraman, M. G.; Lee, Y. R. Photobiol. B: Biol. 2016, 162, 604-610. DOI: 10.1016/j.jphotobiol.2016.07.040.

2. Kiran, S.; Adeel, S.; Nosheen, S.; Hassan, A.; Usman, M.; Rafique, M. A. Adv. Mater. Wastewater Treat. 2017, 29, 29-49. DOI: 10.1002/9781119407805.

3. Naseer, A.; Nosheen, S.; Kiran, S.; Kalam, S.; Javaid, M. A.; Mustafa, M.; Tahir, A. Desalin. Water Treat. 2016, 57, 24070-24082. DOI: 10.1080/19443994.2016.1138145.

4. Gulzar, T.; Huma, T.; Jalal, F.; Iqbal, S.; Abrar, S.; Kiran, S.; Rafique, M. A. Molecules. 2016, 22, 2244. DOI: 1420-3049/22/12/2244.

5. Chatha, S.; Kiran, S.; Gulzar, T., Kamal, S.; Ghaffar, A.; Chatha, M. N. Oxid. Commun. 2016, 39, 1604-1614

6. Gulzar, T.; Kiran, S.; Abrar, S.; Rahmat, M.; Haque, A.; Nosheen, S.; Ahmad, A.; Rasul, S. J. J. Chem. Soc. Pak. 2019, 41, 509

7. Kiran, S.; Nosheen, S.; Iqbal, S.; Abrar, S.; Jalal, F.; Gulzar, T.; Mukhtar, A.; Maqsood, S., Ahmad, W., Nasreen, N. Chiang Mai J. Sci. 2018, 45, 2730-2739. DOI: 6653943832/64235.

8. Kiran, S.; Gulzar, T.; Iqbal, S.; Habib, N.; Hassan, A.; Naz, S. Integ. Green Chem. Sust. Eng. 2019, 473-525. DOI: 10.1002/9781119509868.

9. Haque, A.; Kiran, S.; Nosheen, S.; Afzal, G.; Gulzar, T.; Ahmad, S.; Rehman, S.; Tariq, M. H. Pol. J. Environ. Stud. 2020, 29, 609-616. DOI: 10.15244/pjoes/104663.

10. Abid, P.; Farzi, A.; Karimi, A. J. Tai. Inst. Chem. Engng. 2017, 71, 137-144. DOI: 10.1016/i.jtice.2016.11.022.

11. Kiran, S.; Ali, S.; Asgher, M.; Shahid, S. A. J. Environ. Sci. Water Resour. 2012, 1, 267-275

12. Rasheed, A.; Nosheen, S.; Kiran, S.; Bhatti, H. N.; Kamal, S.; Shamim, F.; Rafique, M. A. Oxid. Commun. 2016, 39, 1716-1726

13. Wang, B.; Dong, F.; Chen, M.; Zhu, J.; Tan, J.; Fu, X.; Chen, S. Procedia. Environ. Sci. 2016, 31, 1217. DOI: $10.1016 /$ j.proenv.2016.02.002. 
14. Kiran, S.; Huma, T.; Jalal, F.; Farooq, T.; Hameed, A.; Gulzar, T.; Bashir, A.; Rahmat, M.; Rahmet, R.; Rafique, M. A. Pol. J. Environ. Stud. 2019, 28, 1749-1757. DOI: 10.15244/pjoes/89575.

15. Manikprabhu, D.; Lingappa, K. J. Pharm. Res. 2013, 6, 255-260. DOI: 10.1016/j.jopr.2013.01.022.

16. Adeoye, A. O.; Lateef, A.; Gueguim-kana, E. B. Biocatal. Agricul. Biotechnol. 2015, 4, 568-574. DOI: 10.1016/j.bcab.2015.08.004.

17. Rosales, E.; Meijide, J.; Tanvares, T.; Pazos, M.; Sanroman, M. A. Process Saf. Environ. Protection. 2016, 101, 61-71. DOI: 10.1016/j.psep.2016.03.006.

18. Fang, R.; Chen, K., Yin, L.; Sun, Z.; Li, F.; Cheng, H. M. Adv. Mater. 2019, 31, 1800863. DOI: 10.1002/adma.201800863.

19. Sharma, A.; Siddiqui, Z. M.; Dhar, S.; Mehta, P.; Pathania, D. Sep. Sci. Technol. 2019, 54, 916-929. DOI: 10.1080/01496395.2018.1524908.

20. Kuchelar, S.; Dhag, P.; Gaikwad, V.; Aher, H.; Han, S. Chem. Sci. 2018, 7, 696. DOI: 10.7589/cst2018.1537.

21. Greenberg, A. E.; Trussell, R. L.; Clesceri, L. S. Standard Methods for the examination of water and wastewater. $20^{\text {th }}$ Ed., 1985.

22. Steel, R. G.; Torrie, O.; Dickey, D. A. Principles and procedures of Statistics: A Biochemical Approach, $3^{\text {rd }}$ Ed.; McGraw Hill, New York, USA, 1997.

23. Santhosh, A. M.; Yogendra, K.; Mahadevan, K. M.; Madhusudhana, N. Int. J. Adv. Res. Sci .Engng. 2017, 6, 51-64.

24. Kiran, S.; Rafique, M. A.; Iqbal, S.; Nosheen, S.; Naz, S. and Rasheed, A. Environ. Sci. Poll. Res., 2020, 27, 32998-33007. DOI: 10.1007/s11356-020-09510-9.

25. Foster, S.L.; Estoque, K.; Voecks, M.; Rentz, N.; Greenlee, L. F. J. Nanomater. 2019, 1, 1-12. DOI: 10.1155/2019/9807605.

26. Zhu, C.; Wang, L.; Kong, L.; Yang, X.; Zheng, S.; Chen, F.; Maizhi, F.; Zong, H. Chemosphere. 2000, 41, 303-309. DOI: 10.1016/S0045-6535(99)00487-7.

27. Chowdhury, S.; Bhattacharyya, K. G. J. Appl. Sci. 2019, 1, 87 DOI: 10.1007/s42452-018-0094-8.

28. Da Silva, B. C.; Zanutto, A.; Pietrobelli, J. M. Adsorpt. Sci. Technol. 2019, 37, 236-259. DOI: 10.1177/0263617418823995.

29. Sharma, A.; Siddiqui, Z. M.; Dhar, S.; Mehta, P.; Pathania, D. Sep. Sci. Technol. 2019, 54, 916-929. DOI: $10.1080 / 01496395.2018 .1524908$.

30. Yasmin, S.; Nouren, S.; Bhatti, H. N.; Iqbal, D. N.; Iftikhar, S.; Majeed, J.; Mustafa, R.; Nisar, N.; Nisra, J., Nazir, A.; Iqbal, M.; Rizvi, H. Green Process. Synth. 2020, 9, 87-96. DOI: 10.1515/gps2020-0010.

31. Viana, D. F.; Salazar-banda, G. R.; Leite, M. S. Sep. Sci. Technol. 2018, 53, 2647-2661. DOI: 10.1080/01496395.2018.1463264.

32. Ferraz, E.; Oliveira, G.; Grando, M. D.; Lizier, T. M.; Zanoni, M.; Oliveria, D. P. J. Environ. Manag. 2013, 124, 108-114. DOI: 10.1016/j.jenvman.2013.03.033.

33. Muneer, M.; Saeed, M.; Bhatti, I. A.; Haq, A. U.; Khosa, M. K.; Jamal, M. A.; Ali, S. Nukleonika 2019, 64, 49-53. DOI: 10.2478/nuka-2019-0006.

34. Harun, N. H.; Rahman, M.; Kamarudin, W.; Irwan, Z.; Muhammud, A.; Akhir, N.; Yaafar, M. R. J. Fund. Appl. Sci. 2018, 10, 832-846. 